April, I928.

\title{
COMPULSORY INSURANCE AGAINST MOTOR VEHICLE ACCIDENTS
}

\author{
Wayland H. Elsbree \\ Harold COOPER Roberts
}

The yearly mounting toll of deaths and injuries resulting from automobile accidents in the United States has been the source of considerable agitation for more drastic regulation of motor vehicles when operated on the public highways. Under their so-called police powers, several states have enacted legislation to safeguard the rights of the victims of such accidents and to provide convenient means for their enforcement. In I923, Massachusetts passed a law declaring that the use of the state's highways by a non-resident motorist shall be deemed equivalent to an appointment by him of the registrar of motor vehicles as his attorney, upon whom process may be served in any action growing out of any accident or collision in which the non-resident motorist may be involved while operating a motor vehicle upon such highways. ${ }^{1}$ Service of a copy of the process upon the defendant is required to be made by registered mail. The Massachusetts Act, recently upheld by the United States Supreme Court $^{2}$ as a reasonable exercise of the police power, was followed by similar measures in Connecticut, New Hampshire, New Jersey and Wisconsin. ${ }^{3}$

In line with these provisions, designed to give a convenient means of redress, there is a growing demand for measures to insure that the remedy afforded shall be of some value. When one considers that more than twice as many people were killed or injured in the United States by automobiles in I926 as there

${ }^{2}$ Mass. Cum. Stat. (i927) c. 90 § 3A.

${ }^{2}$ Hess v. Pawloski, 274 U. S. 352 (I927).

${ }^{3}$ Conn. PUb. Acts (1925) c. I22; N. H. Pub. Laws (1926) c. $100 \S 32 ;$ Wis, Laws (1925) c. $94 ; \mathrm{N}$. J. Comp. Stat. (Cum. Supp. I924) § I35-93 (held unconstitutional by the United States Supreme Court in Wuchter v. Pizzuti, decided Feb. 20, 1928, on the ground that its failure to require notice to the defendant was a violation of the due process clause of the Fourteeenth Amendment). 
were Americans killed or wounded in the Great War, the tremendous economic loss involved becomes evident. The deaths alone are now in excess of twenty-five thousand per year and with the prospect of an increasing number of cars in operation, it is not unreasonable to assume that the number of casualties will continue to be as large if not larger than at the present.

The remedy now most often suggested is a compulsory automobile liability insurance law. It is estimated that not more than twenty percent. of automobile owners in the United States carry liability insurance. A recent survey in New York shows that only seventeen per cent. of the registered cars are insured in that state. The percentage is higher, of course, in the cities than in the country districts. But even in the very large cities with a population exceeding five hundred thousand, probably not more than fifty per cent. of the owners are insured. The person who does not carry insurance is the irresponsible automobile owner of the judgment-proof sort, and instances of persons who have sustained serious injuries and obtained judgments against defendants afflicted with chronic insolvency are no longer rare. It has been estimated that one-fourth of all injured claimants entitled by law to collect fail on account of the defendant's financial irresponsibility. ${ }^{4}$ Possibly this estimate is high, but it must be conceded that the number of such persons is large, and that their inability to collect is a matter of public concern.

The purpose of this article is to discuss the validity of compulsory liability insurance legislation and some possible effects of it, and to suggest the adoption of an alternative measure, basing the right to recovery on compensation, irrespective of the proof of negligence.

In I925, Massachusetts passed a compulsory liability insurance act, it being the first measure of its kind in the country. ${ }^{5}$ A legislative committee, appointed to study motor vehicle problems, had reported that more than twenty thousand persons per

See Compulsory Automobile Insurance, by Harry J. Loman, Professor of Insurance, Wharton School of Finance and Commerce, University of Pennsylvania, in the ANNAIS of THE AMERICAN ACADEMY of Political AND Sociat SCIENCE, March, 1927.

"Mass. Cum. Stat. (1927) c. I75 § II3A. 
year were killed or injured by motor vehicles in Massachusetts, that owners of only about thirty per cent. of the registered automobiles carried insurance, and that large numbers of persons injured and representatives of those killed were unable to obtain redress because of the financial irresponsibility of defendants in suits arising out of such accidents. The Massachusetts Act, in brief, requires that every applicant for registration of a motor vehicle must present a certificate showing that his motor vehicle is covered by a liability bond or an insurance policy, which runs for a period coterminous with the registration, and provides indemnities against loss to the insured and to any person operating or responsible for the operation of the vehicle with his express or implied consent, to the amount of five thousand dollars, on account of injury to or death of any one person, and in the sum of ten thousand dollars, on account of injury to or death of more than one person in any one accident. In lieu of a bond or policy an applicant may deposit cash or securities with the state in the sum of five thousand dollars.

Prior to the final enactment of this measure, the Supreme Judicial Court, at the request of the legislature, rendered an advisory opinion in which it passed upon its constitutionality, and upheld it in every particular. ${ }^{6}$ The court found ample support for its opinion in the broad powers of the Commonwealth to regulate travel on the highways in the public interest, and while admitting that the proposed ban would extend the police power into a new field, it found established precedents in the familiar dangerous instrumentality doctrine, as well as compulsory workmen's compensation acts.

The Act does not apply to non-resident owners not registered in Massachusetts, but the court felt that a classification including only such motor vehicles as were registered was not unreasonable, although the Supreme Court of New Hampshire expressed serious doubt as to the validity of a similar provision in a bill pending before the legislature of that state. ${ }^{7}$ While the

\footnotetext{
- In Re Opinion of the Justices, 25 I Mass. 569, I47 N. E. 68I (I925). (1925).

'Re Opinion of the Justices, 8I N. H. 566, I29 Atl. II7, 39 A. L. R. 1023
} 
Act might well have included non-resident owners, ${ }^{3}$ the distinction created does not appear to amount to unlawful discrimination. It is not necessary that both classes be treated exactly alike. Laws permitting non-resident owners to operate within a state without being registered or obtaining a license are admittedly valid. Motor vehicles owned by the Commonwealth or by street railways under public control are also excluded from the Act. Nor are claims for personal injury or death occurring on private property and claims for property damage provided for.

The Act provides for a board of appeal, before which a person aggrieved by the cancellation of his bond or policy or by the refusal of a surety company or insurance company to issue the same, may appear; and the board shall determine whether or not the cancellation is proper and whether or not the applicant is a proper risk. In sustaining this section of the Act the court recognized it was a serious interference with the insurer's right to freedom of contract. Inasmuch as corporations alone can issue either a policy or bond under the terms of the Act, the power of the state over corporations in general, and insurance corporations in particular, was invoked to justify it. No statements made by or on behalf of the insured and no violations of the terms of the policy are allowed to defeat the claim of a judgment creditor proceeding to collect damages. This provision, in effect, abolishes the defense of fraud by the insurer or surety in so far as the injured claimant is concerned, but power is reserved in the company to cancel the policy or bond on reasonable notice, the cancellation being subject to review by the board of appeal.

As regards the operation of the Massachusetts law no statistics are available, so far as we are aware, showing its effect upon the number of accidents, the proportion of judgments obtained in suits instituted, or the average amount of such judgments. There is no doubt, however, as to the hostility of insurance companies toward it. Whether or not their interests are as seriously jeopardized by the Act as they claim, remains to be seen.

${ }^{8}$ Kane v. New Jersey, 242 U.S. I60 (I9I6); Hendrick v. Maryland, 235 U. S. 6ro (I915). 
The power placed in the hands of the board of appeal to pass upon the fitness of applicants may be effectual in removing many reckless drivers from the highways and in checking the increase in the number of accidents. On the other hand, juries will necessarily know that all defendants are insured, and will be more prone to resolve doubts in favor of plaintiffs. It is not our purpose here to state all the possible arguments that may be urged for and against the law from the standpoint of the insurance companies. Until the facts have been collected and analyzed it is, perhaps, better to withhold judgment.

Meanwhile another type of law, not requiring insurance, but designed to provide some relief to injured claimants, was passed in New Hampshire in $1927 .^{\circ}$ This Act provides for a preliminary court hearing upon the petition of an injured party at which time, if the court is of the opinion that the accident was probably due to defendant's fault, it shall order him to furnish such security as it may see fit to satisfy a judgment against him. If the defendant fails to obtain the security, his license and registration are suspended. The most obvious objection to legislation of this sort is that it locks the stable door after the horse is stolen. If defendant is financially irresponsible, the necessary security will not be forthcoming. Another serious objection to it, certainly in large cities, would be the crowding of court dockets already overloaded with such cases.

It may seriously be questioned whether the automobile has not created a condition that demands treatment radically different from that embodied in compulsory liability insurance laws. Admitting that such measures are enacted in pursuance of the police power of the state, cannot and should not that power be exercised to provide redress for all persons injured in automobile accidents? A law providing compensation for injuries sustained, analogous to workmen's compensation acts now in force, would, it is believed, accomplish this result.

Before inquiring into the constitutionality of a law as above proposed, it is well to see how the existing legal machinery functions. Generally speaking, the right of an injured party to re-

\footnotetext{
${ }^{\circ}$ N. H. LAws (I927) c. 54 .
} 
cover depends upon proof of the defendant's negligence and proof of plaintiff's own freedom from contributory negligence, and he must establish these facts by a fair preponderance of the evidence. The law provides a standard of care by which his conduct is judged, which standard is that of a purely fictitious fellow, sometimes known as the "reasonably prudent man." Admittedly he behaves like none of the human race, for his qualities are not those of the ordinary person, who at one time or another is pretty certain to err. How do such rules apply to automobile accidents? Conceding that responsibility in many cases can be clearly traced to one of the parties, it is still true that in many more cases circumstances beyond the control of both parties are the real causes, and only by invoking an artificial standard of conduct can negligence be attributed to either. If the standard by which the conduct of the parties is judged is artificial, the facts in so far as the jury hear them are usually equally so. Accidents occur and are over in a flash. Years afterward witnesses come into court to testify from memories clouded by the lapse of time. Even though their memories are fresh, the difficulty is that they do not know what really happened. One attempting to visualize the action from such testimony conceives a jumbled mass of moving vehicles, street curbs, car tracks, distances and miles per hour, and gives up in despair. All too frequently it happens that the only evidence which might establish negligence lies buried with the victim. For the rule generally is that there is no presumption in law that a decedent was in the exercise of due care at the time of his death.

It may be argued, of course, that all the rules pertaining to the proof of negligence and due care have been an essential part of the law from the beginning, and that instances of cases wherein the rules work hardship do not warrant their abandonment. However, it should be remembered that the present condition of affairs has been brought about by the automobile. It has revolutionized ways of living and necessitated changes in long-established habits, so that eternal vigilance is the price of safety to all users of the highway today. Just as society has required modern industry to assume its share of responsibility for its victims, by 
the passage of workmen's compensation acts, likewise it seems not unreasonable to believe that legislation providing some form of compensation for those injured on the highway by automobiles will be enacted.

It is not within the scope of this article to discuss in detail the nature of such legislation, but merely to consider certain of the most important objections which may be made on constitutional grounds, to point out its major requirements, and to note certain obstacles in its path. It is, of course, impossible to consider individually the many provisions found in the constitutions of the respective states which might be invoked in an attack upon the validity of such legislation. It must suffice, therefore, to consider the possible objections under the Pennsylvania Constitution and the Federal Constitution, in the hope that this may point the way to the solution of objections based upon provisions of other constitutions more or less similar.

Only two sections of the Constitution of Pennsylvania present real difficulty: Article I, section $6,{ }^{10}$ and Article III, section 2I. ${ }^{11}$ These were urged as objections to the Workmen's Compensation $A c t^{12}$ in the Supreme Court of Pennsylvania, by a workman who, although injured subsequently to the effective day of that statute, sought to maintain an action against his employer at common law. In that case, ${ }^{13}$ the Court held that the inviolate."

"As amended Nov. 2, 1915: "The General Assembly may enact laws requiring the payment by employers, or employers and employes jointly, of reasonable compensation for injuries to employes arising in the course of their employment, and for occupation diseases of employes, whether or not such injuries or diseases result in death, and regardless of fault of employer or employe, and fixing the basis of ascertainment of such compensation and the maximum and minimum limits thereof, and providing special or general remedies for the collection thereof; but in no other cases shall the General Assembly limit the amount to be recovered for injuries resulting in death, or for injuries to persons or property, and in case of death from such injuries, the right of action shall survive, and the General Assembly shall prescribe for whose benefit such actions shall be prosecuted. No act shall prescribe any limitations of time within which suits may be brought against corporations for injuries to persons or property, or for other causes, different from those fixed by general laws regulating actions against natural persons, and such acts now existing are avoided.

${ }^{22}$ Act of 1915, P. L. 736, PA. Stat. (West, 1920) § 21916 et seq.

${ }^{23}$ Anderson v. Carnegie Steel Co., $255 \mathrm{~Pa} .33,99 \mathrm{Atl} .215$ (1916). This case arose prior to the amendment of I9I5 to Article III, $\$ 21$ of the Constitution, which is quoted supra note II, and there, as here, only the general prohibition contained in that section was under consideration. 
optional feature of the Workmen's Compensation Act was a complete answer to the argument that it violated the provisions of the Constitution referred to. In other words, the parties were deprived of a trial by jury, and the amount of recovery was limited, only when the parties had agreed that such should be the case. It was nowhere stated in that opinion that the Act would have been void but for the option given, but that result would seem to follow from the language of earlier decisions. ${ }^{14}$ It is possible, however, that the remedy provided by an act such as that under consideration might be held to be novel, and not within the constitutional restrictions referred to. This is more likely in regard to the requirement of trial by jury, as to which analogies may be found, ${ }^{15}$ than as to limitation of recovery, since the language of the latter clause is far broader.

While there remains always the possibility of constitutional amendment, ${ }^{16}$ it does not seem necessary to resort to that measure in order to achieve the desired end. One possible alternative would be to make this remedy optional with the person injured, so as to avoid constitutional objections on the same ground as that on which the Workmen's Compensation Act was sustained. ${ }^{17}$ While an election prior to the accident, as is the practice under that $A c t$, could not be required, except as mentioned later, such obstacles could be placed in the way of recovery in an action at common law as would prove nearly as effective. ${ }^{18}$ In addition,

${ }^{14}$ Cutler \& Hinds v. Richley, I5I Pa. I95, 25 Atl. 96 (I892) ; Pennsylvania R. R. v. Bowers, I24 Pa. I83, I6 Atl. 836 (I889), and cases there cited. For further decisions on this point, see I PuRd. Dig. (I3th ed. I905) II8, n. (m), (n), rrg, n. (o).

${ }_{15}$ "That the claim of the defendant below was derived from and altogether dependent upon statutory enactment is a sufficient answer to the argument that the Act of Assembly . . is unconstitutional as depriving the defendant of his right to a trial by jury ;" Simpson v. Neill, $89 \mathrm{~Pa}$. I83, I86 (1879). See also Wynkoop v. Cooch, $89 \mathrm{~Pa} .450$ (I879); Rhines v. Clark, 5I Pa. 96 (I866); Commonwealth v. Andrews, 24 Pa. Super. 57 I (I904); Premier Cereal Co. v. Pennsylvania Alcohol Permit Board, Supreme Court of Pennsylvania, decided Jan. 23, I928, not yet reported. For further decisions, see cases collected in I PURD. Dig. (I3th ed. I905) II8, n. (n), IIg n. (o).

${ }^{10}$ This would not present any serious obstacle, especially in view of the precedent already established by the Amendment of I915, providing for workmen's compensation laws. See this section as amended, supra note Ir.

${ }^{27}$ Anderson v. Carnegie Steel Co., supra note I3.

${ }^{18}$ Possible changes in the present law of negligence to make the remedy less attractive are almost countless. Among the most obvious are the requirement 
an affirmative notice of election to sue at common law, to be served personally upon the defendant, within a limited period of time, might be required.

There would seem to be but little difficulty on the constitutional side, so far as objection by the defendant is concerned. Consent to be bound by this legislation might be made a condition of securing registration for an automobile. In view of recent decisions, ${ }^{19}$ especially those of the Supreme Court of the United States, ${ }^{20}$ this requirement certainly would not place an unconstitutional burden upon one desiring to avail himself of the privilege of operating an automobile upon the public highway. As a further development of this right to operate an automobile, every applicant for a driver's license might be required to consent to be bound by the act under consideration as to any injuries sustained by him while operating a car upon the highway.

The Federal Constitution interposes no objection to such a compensatory plan. It is clear from the language of the case just cited ${ }^{21}$ that legislation regulatory of motor, vehicles and their operation stands in a class by itself, by reason of the constant danger to life and property which is involved. It seems, therefore, that the language used by the Supreme Court of the United States in passing upon the constitutionality of the Workmen's Compensation Act of New York ${ }^{22}$ is fully applicable in the situation under consideration:

that the plaintiff shall have the burden of proving not only the defendant's negligence but also his own freedom from contributory negligence; imputation to the plaintiff of the negligence of the driver of the vehicle in which he is riding; denial of recovery whenever the plaintiff or such driver is guilty of any violation of law, whether or not a contributing cause of the accident; denial of recovery to a pedestrian who crosses a street at a place other than on the crosswalk, or while any vehicle is approaching within sight; denial of recovery to any occupant of a vehicle which fails to come to a stop before entering an intersection; requiring the plaintiff to specify precisely and in detail the act of negligence of the defendant on which he relies for recovery, and to establish such act by evidence of the same grade and quality as that which would be required for conviction upon a criminal prosecution for the same acts. Other changes looking toward the same end will doubtless suggest themselves to the reader.

${ }^{10}$ See cases collected in 42 C. J. 6I4 el seq.

${ }^{20}$ Hess v. Pawloski, supra note 2. Cf. Kane v. New Jersey, Hendrick v. Maryland, both supra note 8 .

${ }_{21}$ Hess v. Pawloski, supra note 2.

${ }^{22}$ New York Central R. R. v. White, 243 U. S. I88, 206 (I9I7). 
"The subject-matter, in respect of which freedom of contract is restricted, is the matter of compensation for human life or limb lost or disability incurred in the course of hazardous employment, and the public has a direct interest in this as affecting the common welfare."

And in the other case decided at the same time, ${ }^{23}$ it was added:

"It seems to us that the considerations to which we have adverted in New York C. R. Co. v. White, supra, as showing that the Workmen's Compensation Law of New York is not to be deemed arbitrary and unreasonable from the standpoint of natural justice, are sufficient to support the state of Washington in concluding that the matter of compensation for accidental injuries with resulting loss of life or earning capacity of men employed in hazardous occupations is of sufficient public moment to justify making the entire matter of compensation a public concern, to be administered through state agencies. Certainly the operation of industrial establishments that, in the ordinary course of things, frequently and inevitably produce disabling or mortal injuries to the human beings employed, is not a matter of wholly private concern."

Taking these pronouncements, together with that in Hess $v$. Paruloski, that "Motor vehicles are dangerous machines; and even when skillfully and carefully operated, their use is attended by serious damages to persons and property," scant doubt can remain of the attitude of that Court toward such a scheme of compensation, when the question shall be presented to it.

We come, therefore, to a consideration of the essential features of such an act. The necessity and advisability of making it elective in form, and the changes necessary in the common law remedy in that event have already been considered, and will not be further referred to. The scope of the act should be broad enough to include compensation for all personal injuries sustained, whether by a pedestrian, a driver or passenger in an automobile or other vehicle, in consequence of impact between automobile and pedestrian or between automobiles or between an automobile and another vehicle of any sort, on the highway.

${ }^{23}$ Mountain Timber Co. v. Washington, 243 U. S. 219, 239 (I9I7). 
Injuries sustained in collisions with street railway cars might be included in the compensable class. But collisions between automobile and railway trains or interurban electric railroads should not be included. Injuries sustained by passengers in an automobile by reason of an accident in which no other vehicle is involved should be compensated for, but under such circumstances the driver would be left to his existing remedies at law. These are, of course, no more than tentative suggestions as to the most feasible scope of such an enactment, and experience might show it to be either too broad or too restricted. Grade crossing accidents are not within the purpose of such an act, it seems to the present writers, since the primary cause of such accidents is not the automobile-witness the number of injuries sustained under similar circumstances long before the advent of the "horseless carriage." Provisions similar to those found in most workmen's compensation acts should be incorporated into this act, excluding from its operation injuries caused by the wilful intention of the injured person to injure himself or another, or by his intoxication.

Regardless of whether or not any election is to be given to a person injured under conditions making the act applicable, it would necessarily be a part of such legislation that the filing of a petition under it operate as a waiver of any other rights which the injured person may have, unless it appear upon the hearing of the petition that he is not within the scope of the compensatory act; otherwise, the election thus evidenced to be binding upon the injured party, and his heirs and representatives as well.

Where the person liable for payment of compensation under such an act is also the employer liable under a workmen's compensation act, the provisions of the latter should apply. Where, however, the injured person is within the provisions of both acts and the person liable for payment under each is not the same, the injured may elect under which he will proceed, not being entitled to the benefits of both.

In regard to the amount of compensation payable under such an act, the most feasible plan appears to be the establishment of a fixed weekly sum as compensation for total disability, 
and of a proportionately smaller amount for partial disability. These would be in the nature of a minimum allowance, payable to every person injured under circumstances invoking the application of the statute, without regard to actual loss incurred. In addition to this fixed sum, the reasonable expenses for medical, surgical and hospital services incurred by the claimant should be allowed, with the possible limitation mentioned below. If a claimant sought to recover any greater sum, however, he would be required to assume the burden of proving actual loss of earnings or of profits in the sum claimed, and such greater award, if made, would, of course, be in lieu of, rather than in addition to, the minimum payment discussed above.

This plan would, it is submitted, provide with equal justice for those not employed in gainful occupations, those earning large or small salaries, and those carrying on business individually or in a copartnership, who have experienced great difficulty in actions at common law in proving loss of earnings. Pain and suffering, it will be noticed, have been disallowed altogether as an element of compensation. Further reference will be made to this later, and it is sufficient at this point to remark that any practitioner knows what an elastic and elusive element this may become in the hands of a jury. Since the difficulty would be nearly as great under an act of the nature under consideration, it has seemed best to eliminate this unstable factor.

Whether or not an injured person should be required to accept medical service tendered by the defendant, as is often provided in workmen's compensation acts, is disputable. It is perfectly obvious that many persons would refuse to be attended by a physician unknown to them, and for this reason it seems distinctly unjust to refuse to such persons reasonable medical expenses actually incurred. In any event, prompt notice of injury and prompt submission to medical examination on behalf of the person liable to pay compensation should be made mandatory, on penalty of disallowance of the claim. The other provisons of the local workmen's compensation acts, such as definition of total disability, dependents entitled to compensation, maximum period of compensation, partial permanent disability, and the other de- 
tails, might be embodied in the act under consideration without substantial change.

The machinery necessary to carry into effect this act would not differ essentially from that now existing under the workmen's compensation acts, and no discussion of this phase of the problem seems necessary.

Insurance against such liability should be made mandatory, but whether it should be left to private corporations, be provided for by the state, or both systems maintained, with perhaps the additional feature of self-insurers (under proper restrictions and safeguards) as under the Pennsylvania Workmen's Compensation Act, is largely a matter of policy and of local preference. This is not a problem peculiar to such an act as this, and no doubt the established precedent under the workmen's compensation laws would be followed in any given jurisdiction.

A system of reports to the state department of all accidents occurring, similar to that provided for by the Pennsylvania Workmen's Compensation Act, would no doubt be a desirable feature of the act, not only for statistical purposes, but in order to maintain a record of each driver and of each automobile. Some scheme of blacklisting and refusal of a license to one who reported an excessive number of accidents, or who. failed to report any accident in which he or his automobile was to his knowledge involved, might be added in this connection.

Another problem not yet mentioned is that of liability for property damage. It is obvious that there is not here the same public interest in securing compensation irrespective of fault as exists in the case of personal injuries. Yet to leave these cases to the ordinary procedure of the courts would defeat one of the great aims to be achieved by the act in question, leaving the courts harassed with a large mass of accident litigation, and would require double litigation in a large proportion of cases. The most satisfactory solution would appear to be to utilize the machinery created for the personal injury cases, but to make recovery dependent upon the same elements as are now required, leaving the whole body of the law in that regard unchanged.

This is, of course, a mere summary of the main features of 
an act necessary to secure compensation to those injured by the operation of automobiles, and necessarily omits many phases of the subject altogether. It is indisputable, further, that many objections may be urged against such a plan from an economic and social standpoint, but it is believed that they are far outweighed by the advantages to be gained. At first glance, it may seem that a person injured by an automobile is denied much of his remedy under this plan, but the writers are confident that the remedy actually available would prove much more satisfactory than the present one. The remedy held out by the common law has proven on countless occasions to be a will-o'-the-wisp, seeking which the luckless victim has plunged deep into the bog and mire of legal technicalities. If he does not convict himself of contributory negligence by his own version of the accident, he is apt to discover that he is unable to prove some important element of the loss which he has sustained. Even if he obtains a verdict, it is often a year or more before he sees the fruits of his victory, and, as previously pointed out, there are all too many instances in which he never receives it, the defendant having proven insolvent. And, for one reason or another, it is rarely indeed that he will secure the sum to which the jury declared him entitled.

Another phase of the problem as it now exists, of equal interest to the plaintiff and to the community at large, is the delay in the courts attributable in large measure, if not solely, to the flood of suits arising out of injuries sustained in automobile accidents. This is a matter of public concern, because not only the injured person is without remedy for two or three years, but because other litigation is delayed for the same period of time, with consequent loss and, in many cases, disastrous consequences. It is not uncommon in Philadelphia County for a year or eighteen months to elapse from the time of ordering a case upon the trial list until it appears thereon for the first time. And usually from six months to a year more elapse before there is an opportunity for trial. It is submitted that this situation would be greatly alleviated by the establishment of separate machinery for the trial of cases arising out of automobile accidents, just as the workmen's compensation laws relieved the courts of a great volume of litigation between employer and employed. 